\title{
The Effect of Radiological and Laboratory Parameters on Prognosis in COVID-19 Disease
}

\author{
Kadir Burak Özer, ${ }^{1}$ Berk Çimenoğlu, 9 Attila Özdemir, 9 Mesut Buz, ${ }^{1}$ \\ Kazibe Koyuncu, ${ }^{2}$ Fatih Doğu Geyik, ${ }^{3}$ Recep Demirhan ${ }^{1}$
}

\begin{abstract}
'Department of Thoracic Surgery, Health Sciences University Istanbu Kartal Dr. Lütfi Kırdar City Hospital İstanbul, Turkey

${ }^{2}$ Department of Obstetrics and Gynecology, Health Sciences University Istanbul Kartal Dr. Lütfi Kırdar City Hospital İstanbul, Turkey

${ }^{3}$ Department of Anaesthesiology and Reanimation, Health Sciences University Istanbul Kartal Dr. Lütf Kırdar City Hospital İstanbul, Turkey

Submitted: 16.08 .2020 Accepted: 18.08.2020

Correspondence: Kadir Burak Özer Sağlık Bilimleri Üniversitesi İstanbul Kartal Dr. Lütfi Kırdar Şehir Hastanesi, Göğüs Cerrahi Kliniği, İstanbul, Turkey

E-mail:kdrbrkozer@hotmail.com
\end{abstract}

arads

Keywords: COVID-19

disease; CRP and D-dimer values; CT stage; prognostic cactors.

(c) (i) \&

This work is licensed under a Creative Common Attribution-NonCommercial 4.0 International License.

\begin{abstract}
Objective: A previously unknown contagious disease, which later turned out to be a worldwide pandemic originated from Wuhan, capital of Hubei province in China by the end of 2019. While this upheaval affected numerous countries tragically, mortality rate and necessity for ICU were relatively low in Turkey.
\end{abstract}

Methods: A total of 166 patients (65 at ICU, I0I at pandemic service) were analyzed to uncover effect of radiological and laboratory parameters on prognosis in COVID-19. One hundred and one patients (60.8\%) were treated in pandemic service and 65 (39.15\%) were treated in ICU.

Results: Mean age of the patients in pandemic service was 6I.I 16.2 (23-93) and of patients in ICU was 64.6 \pm 15.7 (15-90) $(p>0.05)$. Initial mean CRP value for pandemic service group was $68.14 \pm 6.5 \mathrm{mg} / \mathrm{dL}(3.1 \mathrm{I}-27 \mathrm{I})$, whereas it was $117.07 \pm 11.5 \mathrm{mg} / \mathrm{dL}(0-360)$ for ICU $(p<0.05)$. Mean D-dimer value for the patients in ICU was $5572.2 \pm 1075.6 \mathrm{ng} / \mathrm{mL}$ and for the patients in pandemic service it was $1904.9 \pm 290.7 \mathrm{ng} / \mathrm{mL}(p<0.05)$. There was a correlation between CRP and D-dimer values $(p<0.05)$. Of 66 patients in ICU group, 30(49.2\%) had early stage CT findings, 22 (36.1\%) had progressing stage CT findings and 9 (14.8\%) had severe stage CT findings. However, of $10 \mathrm{l}$ patients in pandemic service group, 67 (66.9\%) had early stage CT findings, 32 (3I.7\%) had progressing stage CT findings and $2(2 \%)$ had severe stage CT findings.

Conclusion: CT staging is a substantial prognostic factor and may help clinicians decide treatment modality. Furthermore, CRP and D-dimer values are also prognostic during follow-up. Thus, the necessity of taking these parameters into consideration while implementing treatment algorithms has emerged. As a conclusion, CT stage, CRP and D-Dimer values should be adopted as crucial prognostic factors in order to provide efficient healthcare.

\section{INTRODUCTION}

By the end of 2019 , copious patients admitted to healthcare centers with complaints such as cough, fever and respiratory distress in Wuhan, capital of Hubei province in China. All the patients claimed that they developed symptoms after visiting Hubei seafood market. This led authorities activate surveillence system to detect infected patients. Respiratory samples were obtained and studied reference laboratories for detailed etiological research. In 31 December 2019, Chinese Health Organization reported these series of cases to World Health Organization as a probable outbreak.
This specific virus was isolated in respiratory samples in 07 January 2020. This new virus, which exhibited $70 \%$ similarity with SARS-CoV, had never been reported previously in human as a cause of disease and it was named as novel coronavirus (2019-nCoV). Coronavirus is a single stranded RNA virus that is classified within Nestiviridae, Coronaviridae and Orthokinovirus genus. ${ }^{[1-2]}$ This novel virus varies between $60 \mathrm{~nm}$ and $140 \mathrm{~nm}$, and named after the image under electron microscope, which resembles a corona for having spikes on the surface. ${ }^{[3]}$ The disease caused by 2019-nCoV virus was named as COVID-19. Quick transmission from human to human led increasing 
number of patients admit to hospitals. The disease spread across China borders to trigger a worldwide outbreak and first imported case was reported in Thailand 7 days after isolation of the virus. After numerous declerations by many countries, WHO announced this outbreak as a pandemic in II March 2020. Up to date, there are 2.700.000 cases and 185.000 deaths due to COVID-19. ${ }^{4]}$

First case in Turkey was announced in II March 2020 followed by a rapid spread throughout the whole country. By 22 April 2020, a total of 98.674 cases and 2.376 deaths were recorded. Mortality rate and the number of patients in intensive care unit (ICU) were relatively low compared to other countries. ${ }^{[4]}$

In this study we evaluated demographic characteristics, laboratory parameters, computed tomography images and treatment protocols of patients both in ICU and pandemic service. We assessed treatment protocols adopted in Turkey and tried to determine the factors reducing the need for ICU support for patients treated in pandemic service.

\section{MATERIALS AND METHODS}

This study was performed as a retrospective and crosssectional research between 18 March 2020 and 10 April 2020 in a tertiary healthcare center. A total of 166 patients treated in pandemic service and tertiary ICU were included. Age, gender, comorbidities, PCR test results, CT findings; laboratory parameters which are CRP, D-dimer, neutrophil, lymphocyte, white blood cell and platelet counts were analysed through hospital records. Inclusion criteria are being 18 or older, positive PCR test or presence of specific CT findings in patients with negative PCR test and receiving inpatient care.

Although some proven and suspected COVID- 19 patients were sent home with medication for self isolation, some required inpatient treatment and monitoring. Indications for pandemic service follow-up are determined as; fever, desaturation $\left(\mathrm{SpO}_{2}\right.$ in room air <93\%), dyspnea and having a comorbidity. Severe respiratory distress, tachypnea ( $>30 / \mathrm{min}$ ), hypoxia $(<70 \% \mathrm{mmHg})$, and presence of $\mathrm{PaO}_{2} /$ $\mathrm{FiO}_{2}<300$ are considered as indications for ICU follow up. Exclusion criteria are pregnancy, being younger than 18, absence of specific CT findings in patients with negative
PCR test and receiving outpatient care. All retrospective data were analysed and informed consent was obtained from all patients. Approval from Ethics Committee of our Institute was obtained.

Initial CT scan was assessed and radiological findings were classified as early stage, progressing stage and severe stage according to localization, extent and intensity of the lesions. The ground glass opacity (GGO), which is commonly seen in COVID-19 disease, is characterized by an irregular intensity shadow image, especially in the peripheral subpleural region, causing a slight decrease in the local transparency of the lung parenchyma. ${ }^{[5]} \mathrm{K}$. Wang et al. ${ }^{[6]}$ classified CT scan with these paranchymal lesions, which can be detected in lung window, as early stage. CT scan with dense inflammatory infiltrations and central and peribronchial consolidations with or without air bronchograms were classified as progressing stage. Bilateral dense and diffuse consolidations were classified as severe stage. [6] In this study we preferred to categorize CT findings according to above mentioned methodology (Fig. I).

The patients were divided into two groups as patients who were treated in the ICU and pandemic service. All retrospectively collected data were analyzed with Statistical Package for the Social Sciences (SPSS version 22.0, Chicago, IL, USA). Relationship between independent groups were evaluated with Chi-Square test, and analysis of continuous variebles was carried out with Student t-test. One-way ANOVA test was performed for evaluation of relationship between more than two groups. Correlation of two continuous variables were determined by Pearson correlation test. $P$ values lower than 0.05 were accepted as statistically significant.

\section{RESULTS}

Mean age of the patients were $62.47 \pm 16.1$ (18-93). Mean age of the male patients were $60.7 \pm 15.6$ and female patients were $65.4 \pm 16.4$. Out of a total of 166 patients, I0 I $(60.8 \%)$ were treated in pandemic service and 65 (39.15\%) were treated in ICU ( $p>0.05)$. Mean age of the patients in pandemic service was 6I.I $\pm 16.2(23-93)$ and of patients in ICU was 64.6 \pm 15.7 (15-90) ( $>>0.05)$. Differences in mean age between males/females and pandemic service/ ICU groups were not statistically significant ( $p>0.05)$.
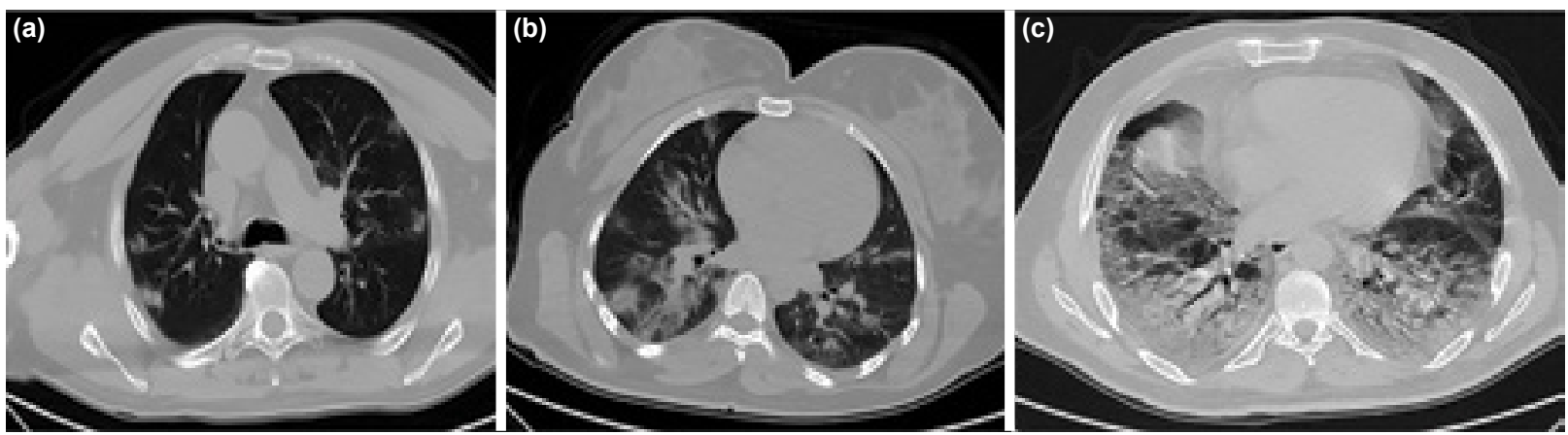

Figure 1. CT findings in Covid-19. (a) Early stage, (b) Progressing stage, (c) Severe stage. 
Table I. Comparison analysis for ICU and Pandemic service group

\begin{tabular}{lccc}
\hline & ICU & Pandemic Service & p value \\
\hline Age & $64.9 \pm 1.5$ & $61.1 \pm 1.6)$ & $>0.05$ \\
Comorbidity, $\mathrm{n}(\%)$ & $55(84.6)$ & $65(64.3)$ & $<0.05$ \\
Neutrophil count $\left(\mathrm{mm}^{3}\right)$ & $7809.3 \pm 758.3$ & $6229.21 \pm 1363.4$ & $>0.05$ \\
& $(600-42000)$ & $(300-136000)$ & $>0.05$ \\
Lymphocyte count $\left(\mathrm{mm}^{3}\right)$ & $1045.3 \pm 202.8$ & $1070.3 \pm 123.5$ & $<0.05$ \\
CRP $(\mathrm{mg} / \mathrm{dL})$ & $(80-11300)$ & $(100-11800)$ & $<8.14 \pm 6.5$ \\
& $117.07 \pm 11.5$ & $(3.11-271)$ & $<0.05$ \\
D-dimer $(\mathrm{ng} / \mathrm{mL})$ & $(0-360)$ & $1904.9 \pm 290.7$ & $<0.05$ \\
CT findings (Early stage \%) & $5572.2 \pm 1075.6$ & $67(66.3)$ & $<0.05$ \\
CT findings (Progressing stage \%) & $30(49.2)$ & $32(31.7)$ & $<0.05$ \\
CT findings (Severe stage \%) & $22(36.1)$ & $2(2)$ & \\
\hline
\end{tabular}

Neutrophil count for the patients in ICU was 7809.3 $\pm 758.7 /$ $\mathrm{uL}(600-42000 / \mathrm{uL})$ and for the patients in pandemic ward was 6229.2I $\pm 1363.4 / \mathrm{uL}(300-136300 / \mathrm{uL})$. Difference between those values was not statistically significant ( $p>0.05)$. Lymphocyte count for the patients in ICU was $1045.3 \pm 202.8 / \mathrm{uL}(80-|| 800 / \mathrm{uL})$ and for the patients in pandemic ward was 1070.3 $\pm 123.5 / 4 \mathrm{~L}$ (100-II800/uL). Difference between these values was not statistically significant $(p>0.05)$ (Table I).

Initial mean CRP value for pandemic service group was $68.14 \pm 6.5 \mathrm{mg} / \mathrm{dL}(3.1 \mathrm{I}-27 \mathrm{I})$, whereas it was II 7.07 \pm I I.5 $\mathrm{mg} / \mathrm{dL}(0-360)$. Difference between these values was statistically significant $(p<0.05)$. Mean $D$-dimer value for the patients in ICU was $5572.2 \pm 1075.6 \mathrm{ng} / \mathrm{mL}$ and for the patients in pandemic service was 1904.9 \pm 290.7 $\mathrm{ng} / \mathrm{mL}$. Difference between these values was statistically significant $(p<0.05)$. A statistically significant positive correlation was observed between CRP and D-dimer values $(p<0.05)$. $D$-dimer values for males were significantly higher than female patients $(3970.43 \pm 6559.15$ vs $2256.5 \pm 3973.19)(p<0.05)$.

Of 66 patients in ICU group, 30 (49.2\%) had early stage CT findings, 22 (36.l\%) had progressing stage CT findings and 9 (14.8\%) had severe stage CT findings. On the other hand, of $10 \mathrm{I}$ patients in pandemic service group, 67 (66.9\%) had early stage CT findings, 32 (31.7\%) had progressing stage CT findings and $2(2 \%)$ had severe stage CT findings. CT findings of patients in ICU were significantly worse $(p<0.05)$ (Fig. 3). CRP/D-dimer values according to CT stage of the patients were compared. This analysis revealed that mean CRP value for early stage CT findings was $63.04 \pm 73$.18, for progessing stage it was $128.34 \pm 78.97$ and for severe stage it was $96.96 \pm 67.76$. Mean D-dimer value for early stage was $2238.38 \pm 3769.69$, for progressing stage it was $5057.8 \pm 8122.42$ and for severe stage it was 3564.55 \pm 4325.68 . The difference between both CRP/Ddimer values for different CT scan stages were statistically significant $(p<0.05)$ (Fig. 2).

Analysing the presence of comorbidities, 52 (80\% within
ICU) patients in ICU and 65 (64.4\% within pandemic service) patients in pandemic service had at least I comorbidity. This difference was statistically significant $(p<0.05)$. Patients who required ICU follow up had a PCR test positivity rate of $65.1 \%$ and patients who were followed up in pandemic ward had a positivity rate of $58 \%$. This difference was not statistically significant. As a result of the statistical comparison of initial PCR test positivity to other parameters and tomography findings, no statistically significant difference was found ( $p>0.05)$ (Fig. 4).

\section{DISCUSSION}

During the COVID-19 pandemic, spreading and mortality rate between countries varies considerably. Sharing useful data on measures and treatment modalities will help us to get through this process with less damage. In this study we combed through patients both in ICU and pandemic service in order to determine the reason why mortality rate and the need for ICU are relatively lower in Turkey compared to other countries. ${ }^{[4]}$ According to a study by Xiaoyi Huang et al.," ${ }^{[7]}$ severity of the disease is correlated with age, as it is more aggressive in patients older than

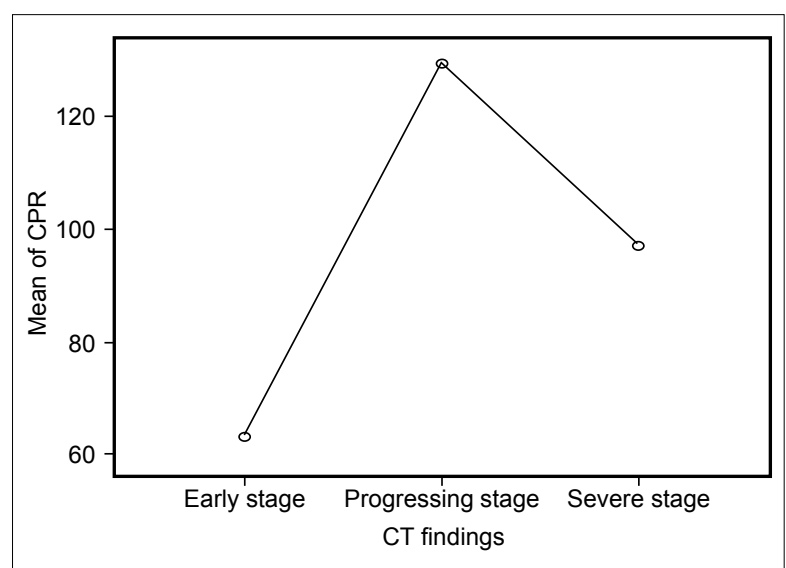

Figure 2. Analysis of CT findings with CRP. 


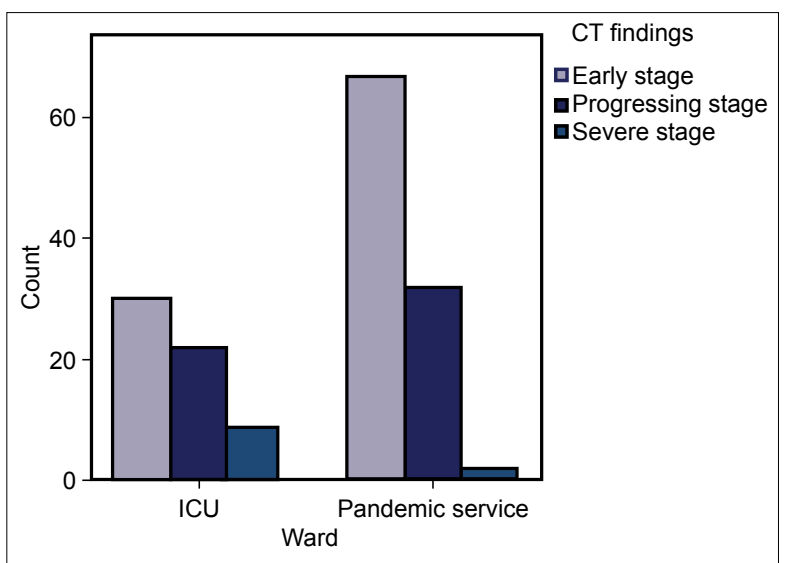

Figure 3. Analysis of CT findings of patients in ICU and pandemic service.

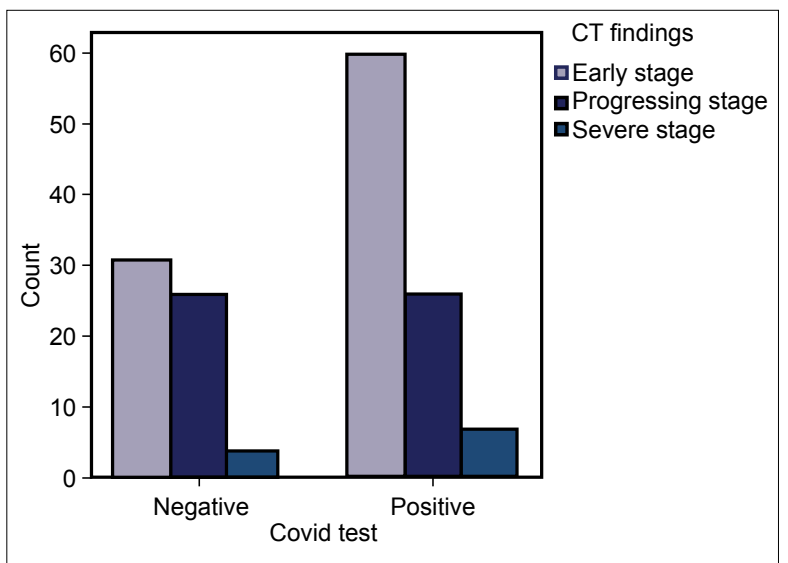

Figure 4. Analysis Analysis of CT findings of patients with positive and negative Covid (PCR) test.

65. ${ }^{[7]}$ However in this study we did not observe any statistically significant age difference between the patients in ICU and pandemic service. Similar to result of a study by Kunhua Li et al.. ${ }^{[8]}$ we realized that need for ICU was higher in patients with at least one comorbidity. ${ }^{[8]}$ Therefore, we may say that having a comorbidity is a crucial prognostic factor and this line of patients should be closely monitored. Effective use of labor force is considered as a very important factor in reducing mortality since the disease is very common. Similarly, curfew on people older than 65 , who tend to be affected by comorbidities, is thought to play an important role in achieving a low mortality rate.

COVID-19 is diagnosed by obtaining a positive result in PCR testing of nasopharyngeal swab sample and/or detecting COVID-19 specific lesions in CT scan. Although we observed a slightly higher positivity rate in PCR test in ICU group, we should keep in mind that symptomatic patients with negative PCR test may require further investigations and/or ICU support. Both PCR test and CT scan can be used as a diagnostic tool in COVID-19 management. In a study by Tao Ai et al., ${ }^{\left[{ }^{9]}\right.} \mathrm{CT}$ scan has a greater sensitivity than PCR testing. ${ }^{[9]}$ However there is still need for further research on sensitivity, specificity and cost ef- fectivity on this issue. However, although it's questionable sensitivity, PCR testing is a mainstay diagnostic tool as it is a criterion to determine which patients should receive plasma therapy. Similar to a study by Rothan et al., ${ }^{[10]}$ our study also suggest that complete blood count analysis has a diagnostic role rather than a prognostic role.

In our study, there is a significant difference of CRP and DDimer values between the patients in ICU and pandemic ward. Furthermore, there is a positive correlation in CRP and $D$-dimer values. Increase in these values may be an indicator of the need for ICU support. Correspondingly, Sun C. et al. ${ }^{[1]}$ reported a similar positive correlation between CRP and D-Dimer values. ${ }^{[1]}$

Radiological investigations on COVID-19 display various images such as ground glass opacity and consolidations. A study conducted by Wang K. et al. ${ }^{[6]}$ suggests patients to be staged according to their CT findings6. Here in this study, we classified patients to 3 radiological stages. Evaluating the relationship between radiological stage and CRP/D-dimer values; early stage CT findings were related with lowest CRP and D-dimer values. CRP and D-dimer values in radiologically severe stage were not as high as progressing stage and this result may be explained by deterioration in immune system as the disease advances. It is vital to initiate antiviral and immune modulator treatment before immune response system starts to worsen. Significant decrease in ICU demand was observed right after prescribing favipiravir for not only patients in ICU, but also for patients in pandemic service.

By evaluating autopsies of 5 COVID-19 patients, Magro et al. ${ }^{[12]}$ reported that there are microthrombi which tend to unite in diverse parts of the body. ${ }^{[2]} \mathrm{Higher} \mathrm{lev-}$ els of $D$-dimer may be a result of prevalent microthrombi in ICU patients. Effective prophylaxis of thrombi in COVID-19 is crucial in terms of reducing morbidity and mortality especially for patients in ICU. Initiating anticoagulant agents to patients with high $\mathrm{D}$-dimer values is a critical point in treatment protocols implemented in Turkey. The reduction in both the death rates and the number of the patients requiring ICU care could be attributed to the introduction of anticoagulant medication to the treatment protochol.

\section{CONCLUSION}

CT staging is a substantial prognostic factor and may help clinicians decide treatment modality. Furthermore CRP and D-dimer values are also prognostic during follow-up. Thus, the necessity of taking these parameters into consideration while implementing treatment algorithms has emerged. As a conclusion, CT stage, CRP and D-Dimer values should be adopted as crucial prognostic factors in order to provide efficent healthcare.

Ethics Committee Approval

Approved by the local ethics committee (date: 29/04/2020, number: 2020/5/4/176/16). 
Informed Consent

Retrospective study.

Peer-review

Internally peer-reviewed.

Authorship Contributions

Concept: K.B.Ö., R.D.; Design: K.B.Ö., A.Ö.; Supervision: B.C., F.D.G.; Materials: K.B.Ö., M.B.; Data: K.B.Ö., B.C.; Analysis: B.C., K.K.; Literature search: K.B.Ö., A.Ö., M.B.; Writing: K.B.Ö., B.C.; Critical revision: K.K., R.D.

Conflict of Interest

None declared.

\section{REFERENCES}

1. Lu H, Stratton CW, Tang YW. Outbreak of pneumonia of unknown etiology in Wuhan, China: The mystery and the miracle. J Med Virol 2020;92:401-2. [CrossRef]

2. Chen N, Zhou M, Dong X, Qu J, Gong F, Han Y, et al. Epidemiological and clinical characteristics of 99 cases of 2019 novel coronavirus pneumonia in Wuhan, China: a descriptive study. Lancet 2020;395:507-13. [CrossRef]

3. Richman DD, Whitley RJ, Hayden FG. Clinical Virology, 4th ed. Washington: ASM Press; 2016. [CrossRef]

4. World health organization coronavirus (covid 19). Available at: https://covid19.who.int Accessed Sep 1, 2020.

5. Guan CS, Lv ZB, Yan S, Du YN, Chen H, Wei LG, et al. Imaging Features of Coronavirus disease 2019 (COVID-19): Evaluation on Thin-Section CT. Acad Radiol 2020;27:609-13. [CrossRef]

6. Wang K, Kang S, Tian R, Zhang X, Zhang X, Wang Y. Imaging manifestations and diagnostic value of chest $\mathrm{CT}$ of coronavirus disease 2019 (COVID-19) in the Xiaogan area. Clin Radiol 2020;75:341-7.

7. Huang X, Wei F, Hu L, Wen L, Chen K. Epidemiology and Clinical Characteristics of COVID-19. Arch Iran Med 2020;23:268-71.

8. Li K, Wu J, Wu F, Guo D, Chen L, Fang Z, et al. The Clinical and Chest CT Features Associated With Severe and Critical COVID-19 Pneumonia. Invest Radiol 2020;55:327-31. [CrossRef]

9. Ai T, Yang Z, Hou H, Zhan C, Chen C, Lv W, et al. Correlation of Chest CT and RT-PCR Testing for Coronavirus Disease 2019 (COVID-19) in China: A Report of 1014 Cases. Radiology 2020;296:E32-E40. [CrossRef]

10. Rothan HA, Byrareddy SN. The epidemiology and pathogenesis of coronavirus disease (COVID-19) outbreak. J Autoimmun 2020;109:102433. [CrossRef]

11. Sun C, Zhang XB, Dai Y, Xu XZ, Zhao J. Clinical analysis of 150 cases of 2019 novel coronavirus infection in Nanyang City, Henan Province. Zhonghua Jie He He Hu Xi Za Zhi 2020;43:503-8.

12. Magro C, Mulvey JJ, Berlin D, Nuovo G, Salvatore S, Harp J, et al. Complement associated microvascular injury and thrombosis in the pathogenesis of severe COVID-19 infection: A report of five cases. Transl Res 2020;220:1-13. [CrossRef]

\section{COVID-19 Hastalı̆ıında Radyolojik ve Laboratuvar Parametrelerinin Prognoza Etkisi}

Amaç: 2019 yılı sonlarına doğru daha önceden bilinmeyen bir hastalık Çin'in Hubei bölgesinin Wuhan kentinde ortaya çıtıtı ve sonrasında dünya çapına yayılarak bir pandemiye dönüştü. Bu salgın birçok ülkeyi etkiledi fakat Türkiye'de diğer ülkelere göre mortalite oranlarının ve yoğun bakım ihtiyacının nispeten daha düşük olduğu gözlemlendi. Bu çalışmamızda servis ve yoğun bakım hastalarını karşılaştırarak serviste takip edilen hastaların, yoğun bakım ihtiyacını azaltan faktörleri değerlendirmeyi amaçladık.

Gereç ve Yöntem: Toplam 166 hasta COVID-19'un radyolojik ve laboratuvar bulgularını ortaya çıkarmak için araştırıldı. Yüz bir (\%60.8) hasta pandemi servisinde, 65 hasta da (\%39.15) yoğun bakım ünitesinde tedavi edildi.

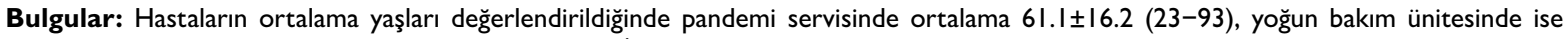
ortalama $64.6 \pm 15.7(15-90)$ olarak saptandı $(p>0.05)$. Illk bakılan ortalama CRP değerleri pandemi servisinde takip edilen hastalarda ortalama $68.14 \pm 6.5 \mathrm{mg} / \mathrm{dl}(3.1 \mathrm{I}-27 \mathrm{I})$, yoğun bakım ünitesinde takip edilen hastalarda ise ortalama II7.07 \pm II.5 mg/dl (0-360) olarak saptandı $(p<0.05)$. Ortalama D Dimer değerleri ise yoğun bakımda takip edilen hastalarda ortalama $5572.2 \pm 1075.6 \mathrm{ng} / \mathrm{ml}$ iken pandemi servisinde takip edilen hastalarda ise ortalama $1904.9 \pm 290.7 \mathrm{ng} / \mathrm{ml}$ olarak belirlendi $(p<0.05)$. D dimer ve CRP değerleri arasında korelasyon izlendi $(p<0.05)$. Yoğun bakım ünitesinde takip edilen 66 hastadan 30'unda $(\% 49.2)$ erken evre BT bulguları, 22'sinde (\%36.I) progresif evre BT bulguları ve 9 (\% I4.8) hastada ise ciddi evre BT bulguları izlendi. Fakat pandemi servisinde tedavi edilen I0I hastanın 67'sinde (\%66.9) erken evre, 32'sinde (\%31.7) progresif evre ve $2(\% 2)$ hastada ise ciddi evre BT bulguları izlendi.

Sonuç: Bu çalışma sonucunda, COVID- 19 hastalığında tomografik evrelemenin ciddi prognostik faktör olduğu ve tedavi protokollerinin buna göre değiştirilebileceği saptanmıştır. Ayrıca laboratuvar testlerinden CRP ve D-dimer'in, hastaların takibi esnasında prognozun belirlenmesinde önemli bir yer tuttuğu gösterilmiştir. Böylelikle tedavi algoritmaları oluştururken bu parametrelerin göz önünde bulundurulması gerekliliği ortaya çıkmıştır. Sonuç olarak, COVID-19 tanılı hastalarda tedavinin başarısı için tomografik evreleme ve CRP ile D-dimer gibi laboratuvar parametrelerinin önemli prognostik faktörler olarak değerlendirilmesi gerekmektedir.

Anahtar Sözcükler: BT evreleri; COVID-19 hastalığ|; CRP ve D-dimer değerleri; prognostik faktörler. 